\title{
Mental Health Outcomes in Northern Italian Workers during the COVID-19 Outbreak: The Role of Demands and Resources in Predicting Depression
}

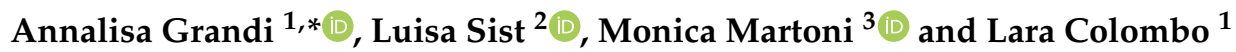 \\ 1 Department of Psychology, University of Turin, 10124 Turin, Italy; lara.colombo@unito.it \\ 2 IRCCS Azienda Ospedaliero-Universitaria di Bologna, 40138 Bologna, Italy; luisa.sist@unibo.it \\ 3 Department of Experimental, Diagnostic and Specialty Medicine, University of Bologna, 40138 Bologna, Italy; \\ monica.martoni@unibo.it \\ * Correspondence: annalisa.grandi@unito.it
}

Citation: Grandi, A.; Sist, L.; Martoni, M.; Colombo, L. Mental Health Outcomes in Northern Italian Workers during the COVID-19 Outbreak: The Role of Demands and Resources in Predicting Depression. Sustainability 2021, 13, 11321. https:/ / doi.org/10.3390/su132011321

Academic Editors: Emanuele

Cannizzaro, Tiziana Ramaci,

Massimiliano Barattucci and Fulvio Plescia

Received: 18 August 2021

Accepted: 8 October 2021

Published: 13 October 2021

Publisher's Note: MDPI stays neutral with regard to jurisdictional claims in published maps and institutional affiliations.

Copyright: (C) 2021 by the authors. Licensee MDPI, Basel, Switzerland. This article is an open access article distributed under the terms and conditions of the Creative Commons Attribution (CC BY) license (https:// creativecommons.org/licenses/by/ $4.0 /)$.

\begin{abstract}
The COVID-19 epidemic caught governments and health authorities off guard and found them unprepared to face its impact on the world population. Italy was the second country after China to face the outbreak of COVID-19 in the first few months of 2020 and the northern part of the country was hit first and most heavily. Following the JD-R theory, an online survey was administered to investigate which specific risk and protective factors predicted depression in a heterogeneous sample of workers. The analyses (analysis of variance, correlations, multiple linear regressions) were run in the total sample and in the sample split by possibility of remote working. The sample consists of 301 workers in northern Italy, 65.1\% being women, and a mean age of 42 years. Depression levels were higher in women and in those who were not able to work remotely. In the total sample, emotional exhaustion at work, sleep-wake cycle problems, and longing for touch were significant predictors of depression. The sample split by the possibility of remote working also showed interesting differences. The results show the importance of monitoring the mental health of workers from professional contexts that are currently less widely studied than the healthcare sector, with particular interest in the possibility of remote working.
\end{abstract}

Keywords: depression; emotional exhaustion; COVID-19; remote work; occupational health

\section{Introduction}

The year 2020 left indelible traces on the world's population. A pandemic of unimaginable proportions caught governments, economies, and international health and prevention authorities off guard. The fallout from this phenomenon has been observed with particular interest in the impact on the psychophysical health of individuals [1], who were put to the test by important-and at the same time sudden — changes in established personal, social, and work habits.

With regard to the personal sphere, the situation of forced lockdown-and for many, even quarantine [2] - has had a serious impact on the daily lives of individuals. It has led to experiences of isolation [3], lack of physical contact [4,5], and increased the risk of domestic conflict [6,7]. In addition, potential exposure to the virus has fostered the onset of fear of being contaminated, which led to avoidance and stigmatization of people potentially carrying the virus [3,8]. A fear of contamination is also reflected in concern for significant others, and in the strong fear that loved ones may become infected and die.

Concerns and worries about the current situation along with the change in lifestyle habits (due to the lockdown) have affected the quality of sleep of individuals. The pandemic situation increased addictive behaviors, including internet use (for a review, see [9]), which can have a meaningful impact on sleep behavior. A worsening of sleep hygiene habits is a factor to be taken seriously, as it has an important effect on mental health; it may, in fact, contribute to the onset of anxious or depressive symptomatology [10-12]. 
In dealing with traumatic events, it is important to remember that there are factors that can play a protective role. Of particular importance is the function of optimism-that is, having positive expectations of the future. This helps maintain the status of individual well-being [13] and protects against the development of depressive symptoms. Social support is an important resource for the maintenance of a decent state of mental health. Receiving a good level of support from friends and family in difficult situations, in fact, decreases the risk of depression [14]. Another resource linked to individual well-being in times of crisis is spirituality, the benefits of which, for some time, have also been studied in the organizational field. In addition to increasing the quality of life of the worker, it gives the worker greater meaning at work and a sense of interconnection with others [15]. Finally, the perception of receiving information in a clear and transparent way from the government and health authorities is considered an important resource with protective value against exposure to the pandemic [3].

As for the occupational world, it has undergone profound changes in the past year. The pandemic situation has led many organizations, for example, to give their workers the opportunity to carry out flexible forms of work in order to continue functioning. Undoubtedly, working remotely has advantages, including, for example, reducing commuting time, saving transport costs for the worker and managing physical workplaces for employers, and increasing productivity [16]. The use of technology (e.g., smartphones) has, on the other hand, made continuous availability through calls (on a corporate or private mobile phone) possible and work emails can be sent and received at any time. Prolonged exposure to a continuous use of technology can lead to what is called techno-stress [17], of which techno-invasion - that is, the use of mobile devices that creates work-life balance problems and prevents recovery [18] - is a factor that contributes to its occurrence. Remote working is linked not only to an increased use of technology but is also associated with the risk of lower well-being, since it often entails longer than normal working hours and greater social isolation $[19,20]$.

Working conditions are important for the health of the individual and we know that job demands can be linked to the onset of emotional exhaustion-the main component of burnout-[21] which is feeling drained of physical and mental energy due to work stress.

Recent studies have shown that-as a consequence of the recent pandemic situationdepression can be a factor of mental malaise in many international contexts [22-26]. Although they are similar constructs, burnout and depression are actually different. Burnout can play the role of mediator between work demands and health problems and even if burnout symptoms, such as loss of interest, depressed mood, and sleep problems, are similar to the symptomatology of depression, a causal connection between them exists [27]. Moreover, several studies have shown how burnout can increase the risk of depression [28,29].

This research is based on the Job Demands-Resources theory (JD-R) [30] that includes specific demands and resources related to specific work contexts. Demands are characteristics typical of an organizational context that involve commitment and effort on the part of the worker. The effect of the latter can be counter-balanced by resources, equally typical of certain contexts, which can be of a physical, social, organizational, or psychological nature; resources also help to achieve goals and stimulate the worker's personal growth. According to this theoretical approach, organizational demands can lead to a process of deterioration of the worker's health, while resources, on the contrary, stimulate a more positive relationship with their work, in terms of motivation or engagement, for example [30].

In line with this theoretical framework, the research model used aims to measure health outcomes in workers in northern Italy - the part of the nation most affected by the initial effects of COVID-19-including work demands and resources and specific demands and resources of the pandemic context. Through a careful analysis of the present literature, it was possible to identify the variables of interest to be included in the research model. The objectives of the present study are (a) to analyze differences in depression, in demands, and in resources according to socio-demographic characteristics and COVID-19 related 
conditions; and (b) to observe which variables better explain depression in workers during the COVID-19 lockdown.

Hypothesis 1 (H1). Specific COVID-19-related demands (fear of contamination, sleep-wake cycle problems, longing for touch, fear of the death of significant others, stigma, domestic aggression, and internet addiction) are positively related to and predict depression.

Hypothesis 2 (H2). Specific work-related demands (relationship with technology outside working hours, work-life conflict and life-work conflict) are positively related to and predict depression.

Hypothesis 3 (H3). Emotional exhaustion at work is positively related to and predicts depression.

Hypothesis 4 (H4). Specific COVID-19 situation personal resources (optimism and spirituality) are negatively related to and predict depression.

Hypothesis 5 (H5). Specific COVID-19 situation resources (social support and adequacy of information) are negatively related to and predict depression.

\section{Materials and Methods}

\subsection{Study Design and Participants}

The present study was approved by the Bioethics Committee of the University of Turin (protocol code no. 181450). The tool used for this research was a questionnaire administered online during the first lockdown in Italy in 2020. A non-probability, purposive sample was employed using the snowball sampling technique. First, the link to the questionnaire was sent to acquaintances with specific features (adult workers in northern Italy) who were asked to forward the link to their contacts with the same characteristics. An explanatory form of the objectives of the research preceded the questionnaire, access to which was possible only after accepting the relative informed consent (in accordance with EU Regulation 2016/679).

Participation in the survey was voluntary; participants did not receive any compensation or benefit. The data were collected between April and May 2020 and involved 301 participants working in northern Italy. Most of the sample consisted of women (65.1\%) and had an average age of 42 years (range $=21-67, \mathrm{SD}=10.72$ ). Regarding marital status, $58.8 \%$ reported being married/cohabiting with a partner, $33.6 \%$ were single, $6.6 \%$ were separated/divorced, and 1\% were widowed. Moreover, 53\% reported having no children. At the time of administration of the questionnaire-during the lockdown-78.1\% reported living with someone, $59.8 \%$ had no pets, and only $2.7 \%$ reported being stuck in a place other than their home.

With regard to the level of education, $63.5 \%$ had a bachelor's degree or post-graduate training, $32.6 \%$ had a high school diploma or vocational school diploma, and $4 \%$ had a lower secondary school diploma. The occupational sectors to which they belonged (described in Table 1) were quite varied but the main fields were education and research $(20.3 \%)$, healthcare services $(14.6 \%)$, industry $(7.6 \%)$, business consulting $(7.3 \%)$, and trade $(7.0 \%)$. The overall average job tenure was 19 years (range $=1-52, \mathrm{SD}=11.22$ ); as for the job contract, most of the sample held a permanent contract $(73.4 \%)$ and worked full-time (78.1\%). Professional categories (Table 1) were also varied and were mainly white collar $(35.2 \%)$, self-employed professional $(17.3 \%)$, and scholar, researcher or teacher $(19.9 \%)$. With regard to remote working, $69.8 \%$ said they had the opportunity to use it and, among these, only $35.6 \%$ had used it - more or less frequently-before the COVID-19 pandemic. Twenty-eight percent said they had to see people (customers/users/patients, etc.) because of their work, despite active restrictions for the COVID-19 emergency. Relating to the changes brought to work as a result of the pandemic, only 37.9\% reported an unchanged situation; $21.3 \%$, on the other hand, were assigned new tasks and 39.9\% had to learn how to use new technological tools. Participants were also asked some questions regarding changes in their habitual consumptions during the lockdown. As far as drinkers $(82.4 \%$ 
out of the total sample) were concerned, $22.6 \%$ claimed that they had increased alcohol (wine, beer) consumption and 7.3\% increased hard liquor consumption. Among smokers (32.6\% out of the total sample), $46.9 \%$ declared an increase in smoking; among those taking psychopharmaceuticals (17.3\% out of the total sample), $19.2 \%$ reported having increased consumption. It should also be noted that $31.2 \%$ of respondents said that a significant other had contracted COVID-19 and 72.4\% said that an acquaintance had contracted the disease.

Table 1. Professional sectors and categories of participants.

\begin{tabular}{|c|c|c|c|c|c|}
\hline \multicolumn{6}{|c|}{ Professional Sectors } \\
\hline & $\mathrm{N}$ & $\%$ & & $\mathrm{~N}$ & $\%$ \\
\hline Agriculture, Handicraft & 10 & 3.4 & Public services and admin. & 25 & 8.3 \\
\hline Business consulting & 22 & 7.3 & Social services & 13 & 4.3 \\
\hline Culture, Sport, Tourism & 25 & 8.3 & Trade/Commerce & 21 & 7.0 \\
\hline Education, Research & 61 & 20.3 & Other & 40 & 13.4 \\
\hline Healthcare services & 44 & 14.6 & & & \\
\hline Industry & 23 & 7.6 & Missing & 3 & 0.9 \\
\hline Mass media, Telecommunications & 14 & 4.6 & & & \\
\hline \multicolumn{6}{|c|}{ Professional categories } \\
\hline & $\mathrm{N}$ & $\%$ & & $\mathrm{~N}$ & $\%$ \\
\hline Blue collar & 10 & 3.3 & Self-employed professional & 52 & 17.3 \\
\hline Educator, Social Worker & 8 & 2.7 & White collar & 106 & 35.2 \\
\hline Healthcare professional & 27 & 9.0 & Other & 17 & 5.6 \\
\hline Manager, Director & 19 & 6.3 & & & \\
\hline Scholar, Researcher, Teacher & 60 & 19.9 & Missing & 2 & 0.7 \\
\hline
\end{tabular}

\subsection{Measures}

For the purposes of the research, scales present in the literature, with good reliability and, where possible, with validation in the Italian language, have been identified and employed. The tools are presented below, divided according to their role as outcomes, as demands, or as resources, following the theoretical model of reference, the JD-R theory [30].

Outcomes. One health outcome was considered:

Depression was measured with the PHD-8 [31], an 8-item measure on a 4-point response Likert scale ( 0 = never, 3 = nearly every day); an example item is: "Over the last week, how often have you been bothered by little interest or pleasure in doing things?" In the sample studied, EFA (ML extraction, 48.89\% explained variance with factor loadings ranging from 0.493 to 0.814 ) resulted in a one-factor solution; the scale showed good reliability (McDonald's $\omega=0.883$ ).

One work-related outcome was also included, even though it was considered as an independent variable in the analysis model:

Emotional exhaustion at work was measured with the 8-item scale of the Oldenburg Burnout Inventory (OLBI) [32] on a 4-point response Likert scale ( 1 = strongly disagree, 4 = strongly agree); a sample item is: "There are days when I feel tired before I arrive at work". In the study sample, EFA (ML extraction, 36.63\% explained variance with factor loadings ranging from 0.402 to 0.775 ) resulted in a one-factor solution; the scale has good reliability (McDonald's $\omega=0.818$ ).

Demands. Seven COVID-19-related demands were considered:

Fear of contamination was measured with 9 items from the PADUA-PI subscale [33], on a 5 -point response Likert scale ( $0=$ not at all, $4=$ very much); an example item is: "I find it difficult to touch an object when I know it has been touched by strangers or by certain people". In the sample studied, EFA (ML extraction, 45.99\% explained variance with factor loadings ranging from 0.518 to 0.774 ) showed the presence of a single factor; the scale showed a good reliability value (McDonald's $\omega=0.883$ ).

Sleep-wake cycle problems were measured with the 10-item Mini Sleep Questionnaire (MSQ) [34] on a 7-point response Likert scale ( $1=$ never, $7=$ always); a sample item is: "How often, in the last 7 days, have you had difficulty falling asleep?" In our sample, EFA (ML 
extraction, $44.80 \%$ explained variance with factor loadings ranging from 0.229 to 0.848 ) showed the presence of a single factor; the scale has a good reliability value (McDonald's $\omega=0.882$ ).

Longing for touch was measured with the 4-item subscale of the Touch Deprivation Scale [35], on a 5-point response Likert scale ( 1 = strongly disagree, $5=$ strongly agree); an example item is: "Some days I long to be held, but have no one to hold me". In the sample studied, EFA (ML extraction, 58.89\% explained variance with factor loadings ranging from 0.662 to 0.871 ) showed the presence of a single factor; the scale has a good reliability value (McDonald's $\omega=0.843$ ).

Fear of the death of significant others was measured with the 6 items of the Multidimensional Fear of Death Scale (MFODS)'s Fear for Significant Others subscale [36], on a 7-point response Likert scale ( 1 = strongly disagree, 7 = strongly agree); an example item is: "I fear people in my family dying". In the sample studied, EFA (ML extraction, 39.04\% explained variance with factor loadings ranging from 0.423 to 0.826 ) showed the presence of a single factor; the scale has a good reliability value (McDonald's $\omega=0.757)$.

Stigma was measured with an adapted version of the Wahl's stigma scale [37], on a 5-point response Likert scale ( $1=$ totally false to me, $5=$ totally true to me). The scale includes 3 items adapted from the original scale (e.g., "I am worried that others will view me unfavorably because I have been-or I might have been-infected"). In our sample, EFA (ML extraction, $32.37 \%$ explained variance with factor loadings ranging from 0.642 to 0.723 ) showed a one-factor solution; the scale has a discreet reliability value (McDonald's $\omega=0.716$ ).

Domestic aggression was measured with 3 items from the Conflict Tactics Scale (CTS2)'s subscale Psychological Aggression [38,39], on a 5-point response Likert scale (1 = never, 5 = every day); a sample item is: "During the last 7 days, my partner or the persons that live with me shouted or yelled at me". In the sample, EFA (ML extraction, 58.24\% explained variance with factor loadings ranging from 0.606 to 0.887 ) showed the presence of a single factor; the scale showed good reliability (McDonald's $\omega=0.824$ ).

Internet addiction was measured with the 6-item Internet Addiction Scale [40], on a 5-point response Likert scale ( $1=$ never, $5=$ often); an example item is: "I spend time using the internet more than I plan to". In the sample, EFA (ML extraction, 38.19\% explained variance with factor loadings ranging from 0.310 to 0.850 ) showed a one-factor solution; the scale has a discreet reliability value (McDonald's $\omega=0.738)$.

Three further demands concerning the working environment were also considered:

Relationship with technology outside working hours was measured with 4 ad hoc items, on a 5 -point response Likert scale ( $1=$ totally disagree, $5=$ totally agree); a sample item is: "I often use the PC and/or the company mobile phone (or my private mobile phone) for work matters". In the sample, EFA (ML extraction, 50.77\% explained variance with factor loadings ranging from 0.449 to 0.897 ) showed the presence of a single factor; the scale has a discreet reliability value (McDonald's $\omega=0.779)$.

Work-life conflict was measured with the 5-item Work-Family Scale [41,42], on a 6-point response Likert scale ( $1=$ never, $6=$ always); a sample item is: "Things I want to do at home do not get done because of the demands my job puts on me". In our sample, EFA (ML extraction, $64.88 \%$ explained variance with factor loadings ranging from 0.705 to 0.914 ) showed the presence of a single factor; the scale has a good reliability value (McDonald's $\omega=0.895$ ).

Life-work conflict was measured with the 5-item Family-Work Scale [41,42], on a 6-point response Likert scale ( $1=$ never, 6 = always); a sample item is: "Family-related strain interferes with my ability to perform job-related duties". In the sample, the EFA (ML extraction, $56.72 \%$ explained variance with factor loadings ranging from 0.515 to 0.879 ) showed the presence of a single factor; the scale has a good reliability value (McDonald's $\omega=0.842$ ).

Resources. Two personal resources were considered:

Optimism was measured with the 6 item-Revised Life Orientation Test $[43,44]$ on a 6-point response Likert scale ( 1 = disagreement, 6 = agreement); an example item is: "In uncertain times, I usually expect the best". In the sample, EFA (ML extraction, 50.15\% explained variance with factor loadings ranging from 0.419 to 0.811 ) showed the presence of a single factor; the scale has a good reliability value (McDonald's $\omega=0.848)$. 
Spirituality was measured with 3 items from The Daily Spiritual Experience Scale [45] with a 4-point response Likert scale $(0=$ not at all, $3=$ totally); an example item is: "I find strength in my religion or spirituality". In the sample, EFA (ML extraction, $92.16 \%$ explained variance with factor loadings ranging from 0.914 to 0.993 ) showed the presence of a single factor; the scale showed very good reliability (McDonald's $\omega=0.974)$.

Two other resources were also considered:

Social support was measured with 6 items from the ENRICHD Social Support Instrument (ESSI) [46], on a 5-point response Likert scale $(1=$ never, $5=$ all the time); an example item is: "There is someone available to whom you can count on to listen to you when you need to talk". In the sample, EFA (ML extraction, $60.29 \%$ explained variance with factor loadings ranging from 0.448 to 0.925 ) showed the presence of a single factor; the scale has a good reliability value (McDonald's $\omega=0.870$ ).

Adequacy of information was measured with a 3-item scale created ad hoc, based on potential stressors experienced during quarantine identified by Brooks and colleagues [3], on a 5 -point response Likert scale ( $1=$ totally disagree, $5=$ totally agree); an example item is: "The government and the healthcare authorities are transparent about the real level of risk due to the spread of COVID-19". In the sample, EFA (ML extraction, 53.70\% explained variance with factor loadings ranging from 0.625 to 0.854 ) showed the presence of a single factor; the scale has a discreet reliability value (McDonald's $\omega=0.772)$.

A section was also included to collect socio-demographic data: age, gender, marital status, cohabitation status, and some job characteristics (e.g., sector, job tenure, working time).

\subsection{Data Analysis}

Preliminary analyses were carried out on the psychometric characteristics of the scales, calculating their factorial structure (EFA) and their reliability through McDonald's $\omega$ [47].

After descriptive data analysis (means and standard deviations of the scales, see Table 2), Pearson's correlations between all variables were calculated on the total sample and on the subsample (possibility of remote working/without the possibility of remote working). Multiple linear regression analyses were also run in order to identify the role of resources, demands, and emotional exhaustion at work as predictors of depression in the total sample and in the subsamples. In all the regression models, multicollinearity among the variables was assessed using the variance inflation factor (VIF): no multicollinearity problem was observed $(\mathrm{VIF}<5)$. The differences between groups in the variables' means were analyzed through the analysis of variance (t-tests for independent samples and one-way ANOVA). The data were analyzed using IBM SPSS 27.

Table 2. Means, standard deviations of the scales, and observed ranges for each variable.

\begin{tabular}{clll}
\hline & MEAN & SD & RANGE \\
\hline Outcomes & & & 0.33 \\
Depression & 1.01 & 0.22 & $1-4$ \\
Emotional Exhaustion at Work & 2.35 & & $0-4$ \\
Demands & & 0.46 & $1-7$ \\
Fear of contamination & 3.34 & 0.64 & $1-5$ \\
Sleep-wake cycle problems & 3.09 & 0.15 & $1-7$ \\
Longing for touch & 2.35 & 0.93 & $1-5$ \\
Fear of the death of significant others & 5.54 & 0.31 & $1-5$ \\
Stigma & 1.65 & 0.24 & $1-5$ \\
Domestic aggression & 1.61 & 0.78 & $1-5$ \\
Internet addiction & 2.38 & 0.53 & $1-6$ \\
Relationship with technology & 2.63 & 0.24 & $1-6$ \\
Work-life conflict & 2.86 & 0.26 & $1-6$ \\
Life-work conflict & 1.84 & & $1-5$ \\
Resources & & 0.23 & $1-5$ \\
\hline Optimism & 3.92 & 0.09 & \\
Spirituality & 1.08 & 0.28 & 0.13 \\
Social support & 4.14 & & \\
\hline Adequacy of information & 2.78 & & \\
\hline
\end{tabular}




\section{Results}

\subsection{Differences between Groups}

Depression was below the average scale score $(\mathrm{M}=1.01, \mathrm{SD}=0.33)$, with higher values in women $(\mathrm{M}=8.69, \mathrm{SD}=5.46)$ than in men $(\mathrm{M}=6.92, \mathrm{SD}=6.53), \mathrm{t}(182.94)=-2.36$, $p=0.019$, Cohen's $\mathrm{D}=0.30$. Those who stated that they did not have the opportunity to work remotely reported higher levels of depression $(\mathrm{M}=9.28, \mathrm{SD}=5.93)$ than those who did have this possibility $(\mathrm{M}=7.55, \mathrm{SD}=5.83), \mathrm{t}(297)=-2.34, p=0.020$, Cohen's $\mathrm{D}=0.30$.

Emotional exhaustion at work was slightly higher than the average scale score $(\mathrm{M}=2.35, \mathrm{SD}=0.22)$, with a higher perception in women $(\mathrm{M}=19.62, \mathrm{SD}=4.58)$ than in men $(\mathrm{M}=17.29, \mathrm{SD}=4.88), \mathrm{t}(284)=-3.98, p<0.001$, Cohen's $\mathrm{D}=0.50$. Those who had a loved one affected by COVID-19 showed a greater perception of emotional exhaustion $(\mathrm{M}=19.70, \mathrm{SD}=4.70)$ than those who were not in this situation $(\mathrm{M}=18.42, \mathrm{SD}=4.81)$, $\mathrm{t}(284)=2.11, p=0.035$, Cohen's D $=0.27$.

Fear of contamination was higher than the average scale score $(\mathrm{M}=3.34, \mathrm{SD}=0.46)$, with no significant differences in gender. Those who stated that they did not have the opportunity to work remotely showed higher levels $(\mathrm{M}=21.26, \mathrm{SD}=8.34)$ than those who did have this possibility $(\mathrm{M}=18.43, \mathrm{SD}=8.23), \mathrm{t}(297)=-2.71, p=0.007$, Cohen's $\mathrm{D}=0.34$.

With regards to sleep-wake cycle problems, the data show values that fall below the average scale score $(\mathrm{M}=3.09, \mathrm{SD}=0.64)$; no significant differences were found in relation to gender. Those who stated that remote working was not an option for them showed more sleep problems $(\mathrm{M}=33.99, \mathrm{SD}=13.22)$ than those who had this possibility $(\mathrm{M}=29.54$, $\mathrm{SD}=12.54), \mathrm{t}(297)=-2.76, p=0.006$, Cohen's $\mathrm{D}=0.35$.

Longing for touch was close to the average scale score $(M=2.35, S D=0.15)$, without significant gender differences. Higher values were found in participants with children $(\mathrm{M}=10.00, \mathrm{SD}=5.14)$ than those who had no children $(\mathrm{M}=8.71, \mathrm{SD}=4.60), \mathrm{t}(299)=-2.27$, $p=0.024$, Cohen's $\mathrm{D}=0.42$. Those who stated that they lived alone during lockdown showed a greater longing for touch $(\mathrm{M}=12.03, \mathrm{SD}=5.07)$ than those living with other people $(\mathrm{M}=8.66, \mathrm{SD}=4.64), \mathrm{t}(299)=5.10, p<0.001$, Cohen's $\mathrm{D}=0.71$. Analysis of variance also showed that age has a significant effect on the desire for physical contact, $\mathrm{F}(4,296)=2.55, p=0.039$, where participants in the 21-29 age group have higher values $(\mathrm{M}=11.16, \mathrm{SD}=5.75)$ than those in the $50-59$ age group $(\mathrm{M}=8.32, \mathrm{SD}=4.56)$.

Fear of the death of significant others was much higher than the average scale score $(\mathrm{M}=5.54, \mathrm{SD}=0.93)$, with a higher level found in women $(\mathrm{M}=34.30, \mathrm{SD}=5.94)$ than in men $(\mathrm{M}=31.36, \mathrm{SD}=6.68), \mathrm{t}(299)=-3.91, p<0.001$, Cohen's D = 0.47. Participants who do not have children reported higher levels $(\mathrm{M}=34.50, \mathrm{SD}=5.64)$ than those with children $(\mathrm{M}=31.86, \mathrm{SD}=6.83), \mathrm{t}(270.07)=-3.63, p<0.001$, Cohen's $\mathrm{D}=0.47$.

The perception of stigma due to actual or potential COVID-19 infection was lower than the average scale score $(\mathrm{M}=1.65, \mathrm{SD}=0.31)$, with a higher level in men $(\mathrm{M}=5.43$, $\mathrm{SD}=2.85)$ than in women $(\mathrm{M}=4.70, \mathrm{SD}=2.42), \mathrm{t}(185.168)=2.23, p=0.027$, Cohen's $\mathrm{D}=0.28$. Those who stated that they did not have the option to work remotely reported a greater perception of stigma $(\mathrm{M}=5.70, \mathrm{SD}=3.22)$ than those who had this possibility $(\mathrm{M}=4.60, \mathrm{SD}=2.15), \mathrm{t}(122.708)=-2.96, p=0.004$, Cohen's $\mathrm{D}=0.44$. Participants who had to see people (customers/users/patients, etc.) because of their work, despite active restrictions for the COVID-19 emergency, reported a higher level of stigma $(\mathrm{M}=5.98, \mathrm{SD}=3.14)$ compared to those who did not $(\mathrm{M}=4.55, \mathrm{SD}=2.23), \mathrm{t}(118.998)=3.83$, $p<0.001$, Cohen's $\mathrm{D}=0.57$. Those who had a loved one affected by COVID-19 showed a greater perception of stigma $(\mathrm{M}=5.54, \mathrm{SD}=3.01)$ compared to those who had not been in this situation $(\mathrm{M}=4.69, \mathrm{SD}=2.34), \mathrm{t}(146.161)=2.44, p=0.016$, Cohen's $\mathrm{D}=0.33$. Those who had an acquaintance (with whom they did not have a close relationship) affected by COVID-19 reported a higher perception of stigma $(\mathrm{M}=5.12, \mathrm{SD}=2.77)$ compared to those who had not been in this situation $(\mathrm{M}=4.51, \mathrm{SD}=2.03), \mathrm{t}(201.399)=2.12, p=0.035$, Cohen's $\mathrm{D}=0.24$.

Domestic aggression suffered in the home environment showed a lower value than the average scale score $(\mathrm{M}=1.61, \mathrm{SD}=0.24)$, without differences in gender. Participants 
with children reported higher levels $(M=5.16, S D=2.60)$ than those without $(M=4.40$, $\mathrm{SD}=2.07), \mathrm{t}(230)=2.49, p=0.013$, Cohen's $\mathrm{D}=0.32$.

Internet addiction was close to the average scale score $(\mathrm{M}=2.38, \mathrm{SD}=0.78)$ and was found to be higher in men $(M=15.11, S D=4.55)$ than in women $(M=13.81, S D=4.66)$, $\mathrm{t}(299)=2.34, p=0.020$, Cohen's D $=0.28$. No other significant differences emerged.

Relationship with technology outside working hours was slightly higher than the average scale score $(\mathrm{M}=2.63, \mathrm{SD}=0.53)$, with no significant differences regarding gender. Those who have children showed a worse situation $(\mathrm{M}=11.55, \mathrm{SD}=4.72)$ than those without $(\mathrm{M}=9.68, \mathrm{SD}=4.13), \mathrm{t}(283)=3.58, p<0.001$, Cohen's $\mathrm{D}=0.43$. Those who had to learn how to use new technological tools at work showed higher levels of addiction regarding out-of-hours technology $(\mathrm{M}=11.33, \mathrm{SD}=4.66)$ than those who were not required to attain this new competence $(\mathrm{M}=9.97, \mathrm{SD}=4.32), \mathrm{t}(282)=2.52, p=0.012$, Cohen's $\mathrm{D}=0.30$.

Work-life conflict reported values that were slightly below the scale average $(\mathrm{M}=2.86$, $\mathrm{SD}=0.24$ ), with no significant differences concerning gender. Those who had a loved one suffering from COVID-19 showed a greater perception of conflict $(\mathrm{M}=16.18, \mathrm{SD}=6.93)$ compared to those who had not been in this situation $(\mathrm{M}=13.45, \mathrm{SD}=5.66), \mathrm{t}(145.35)=3.27$, $p=0.001$, Cohen's $\mathrm{D}=0.45$. Those who had an acquaintance (with whom they did not have a close relationship) affected by COVID-19 reported higher values of exhaustion $(\mathrm{M}=14.75$, $\mathrm{SD}=6.33)$ compared to those who had not been in this situation $(\mathrm{M}=13.09, \mathrm{SD}=5.73)$, $\mathrm{t}(285)=2.01, p=0.045$, Cohen's D $=0.27$.

Life-work conflict showed lower values than the scale average $(\mathrm{M}=1.84, \mathrm{SD}=0.26)$, with no significant differences in gender. Those with children showed higher values $(\mathrm{M}=10.21, \mathrm{SD}=4.37)$ than those without $(\mathrm{M}=8.40, \mathrm{SD}=4.10), \mathrm{t}(276)=3.55, p<0.001$, Cohen's D $=0.43$.

Optimism was higher than the average scale score $(\mathrm{M}=3.92, \mathrm{SD}=0.23)$, with no significant gender differences. Participants with children reported higher levels $(\mathrm{M}=24.62$, $\mathrm{SD}=6.17)$ than those who did not have children $(\mathrm{M}=22.61, \mathrm{SD}=6.19), \mathrm{t}(299)=2.80$, $p=0.005$, Cohen's $\mathrm{D}=32$. Those living with other people during the lockdown showed higher levels of optimism $(\mathrm{M}=24.00, \mathrm{SD}=6.38)$ compared to those living alone $(\mathrm{M}=21.94$, $\mathrm{SD}=5.54), \mathrm{t}(299)=-2.38, p=0.018$, Cohen's $\mathrm{D}=0.33$.

Spirituality was slightly lower than the average scale score $(\mathrm{M}=1.08, \mathrm{SD}=0.09)$, with no significant gender differences. Participants with children showed higher levels $(\mathrm{M}=3.64, \mathrm{SD}=3.29)$ than those without $(\mathrm{M}=2.88, \mathrm{SD}=3.14), \mathrm{t}(299)=2.05, p=0.041$, Cohen's $\mathrm{D}=23$. Those with a loved one suffering from COVID-19 showed higher levels of spirituality $(\mathrm{M}=3.81, \mathrm{SD}=3.17)$ than those who were not in this situation $(\mathrm{M}=2.98$, $\mathrm{SD}=3.23), \mathrm{t}(299)=2.09, p=0.038$, Cohen's $\mathrm{D}=0.26$.

Social support was significantly higher than the average scale score $(\mathrm{M}=4.14, \mathrm{SD}=0.28)$, without significant gender differences. Those living with other people at the time of lockdown reported a greater perception of social support $(\mathrm{M}=25.84, \mathrm{SD}=4.71)$ compared to those living alone $(\mathrm{M}=21.24, \mathrm{SD}=5.55), \mathrm{t}(299)=-6.73, p<0.001$, Cohen's $\mathrm{D}=0.94$.

The perception of adequacy of the information provided by the government and health institutions was slightly higher than the average scale score $(M=2.78, S D=0.13)$, without significant differences regarding gender. Those who had the opportunity to work remotely reported a perception of greater adequacy of information $(\mathrm{M}=8.61, \mathrm{SD}=2.86)$ compared to those who did not have this possibility $(\mathrm{M}=7.65, \mathrm{SD}=3.21), \mathrm{t}(150.15)=2.44$, $p=0.016$, Cohen's D $=0.32$.

\subsection{Correlations and Regressions}

Correlations in the total sample were calculated between depression, demands, and resources; Pearson's coefficients are shown in Table 3. All significant correlations are in the expected direction. Emotional exhaustion at work-as earlier explained-was considered as an independent variable in the analysis model and showed a strong positive correlation $(p<0.01)$ with depression. As expected, depression shows strong positive correlations $(p<0.01)$ both with COVID-19-related demands-fear of contamination, sleep-wake cycle 
problems, longing for touch, fear of the death of significant others, stigma, domestic aggression, and internet addiction — and with work-related demands, that is, relationship with technology, work-life conflict, and life-work conflict. Regarding significant relations with resources, social support and optimism show a strong negative correlation $(p<0.01)$ with the dependent variable, while spirituality and the adequacy of information have negative correlations with depression at a $<0.05$ significance level.

In order to understand which demands and which resources were better predictors of depression, multiple regression analyses were conducted. As shown in Table 4, only two COVID-19-related demands were positively and significantly associated with the dependent variable, namely, sleep-wake cycle problems $(\beta=0.619)$ and longing for touch $(\beta=0.135)$. Emotional exhaustion at work also revealed a positive and significant association with depression $(\beta=0.116)$.

Analyses with the sample split by the possibility of remote working were also conducted. Correlations between depression, demands, and resources are presented in Table 5 . All significant correlations are in the expected direction.

Regarding the part of the sample that had the possibility of remote working, depression had strong positive correlations $(p<0.01)$ with most of the COVID-19-related demands: fear of contamination, sleep-wake cycle problems, longing for touch, fear of the death of significant others, stigma, and internet addiction. A positive correlation with domestic aggression at a $<0.05$ significance level was also found for this group, with strong positive relations $(p<0.01)$ with work-related demands-that is, relationship with technology, work-life conflict, and life-work conflict. The dependent variable showed strong negative correlations $(p<0.01)$ with resources, optimism, social support, and adequacy of information and a significance level of $<0.05$ with spirituality. Emotional exhaustion at work — considered as an independent variable—showed a strong positive correlation $(p<0.01)$ with depression. Multiple linear regression analyses (see Table 6$)$ revealed that two COVID-19-related demands, sleep-wake cycle problems $(\beta=0.588)$ and longing for touch $(\beta=0.145)$, and one work-related demand, relationship with technology $(\beta=0.117)$, were positively associated with depression. As for the resources, spirituality $(\beta=-0.114)$ showed a negative association with the dependent variable. Furthermore, emotional exhaustion at work $(\beta=0.160)$ revealed a positive association with depression.

The analyses conducted in the part of the sample that included those who did not have the option of remote working showed that depression had strong positive correlations $(p<0.01)$ with two of the COVID-19-related demands-sleep-wake cycle problems and internet addiction-and positive correlations at a significance level of $<0.05$ with fear of contamination and stigma. The dependent variable also had a strong positive relation $(p<0.01)$ with a work-related demand, life-work conflict, and a positive correlation at a significance level of $<0.05$ with work-life conflict. No significant correlations were present in regard to resources. Multiple linear regression analyses (see Table 6) revealed that two COVID-19-related demands-sleep-wake cycle problems $(\beta=0.652)$ and internet addiction $(\beta=0.215)$-were positively associated with depression. A work-related demand, life-work conflict $(\beta=0.258)$, was also positively associated with the dependent variable. 
Table 3. Total sample correlations $(\mathrm{N}=301)$.

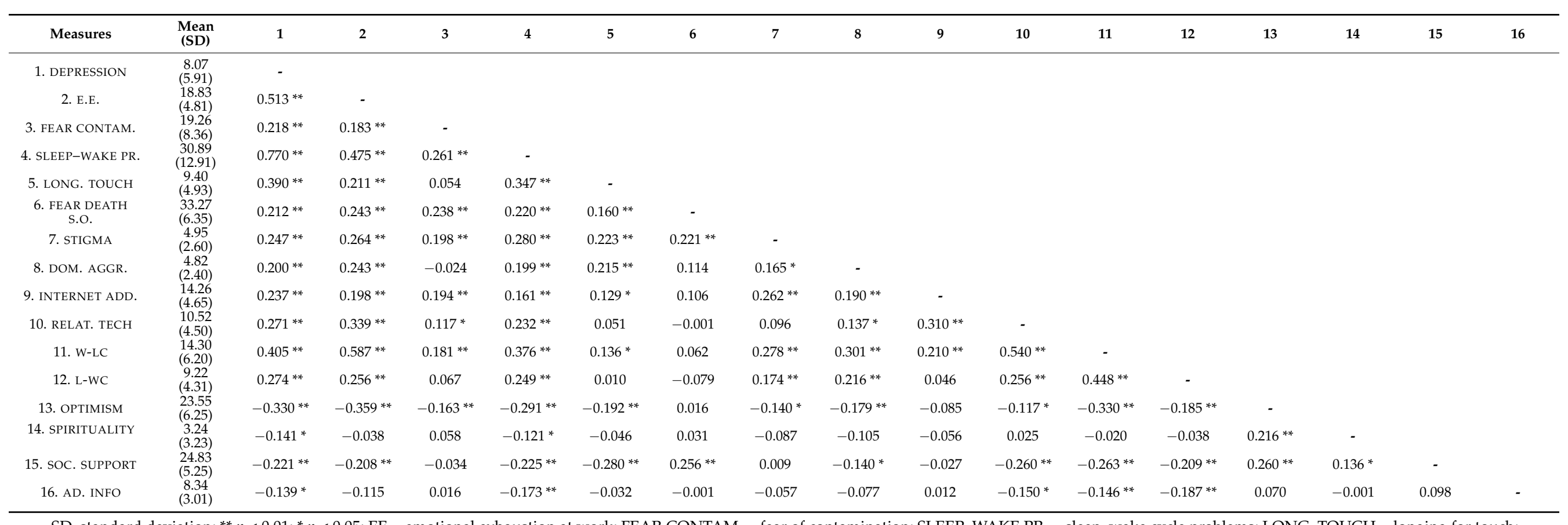

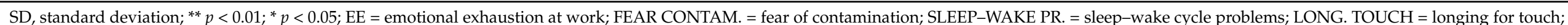

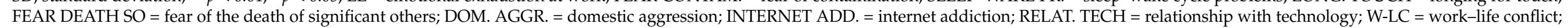

$\mathrm{L}-\mathrm{WC}=$ life-work conflict; SOC. SUPPORT = social support; AD. INFO = adequacy of information. 
Table 4. Regression model in the total sample (depression = dependent variable).

\begin{tabular}{|c|c|c|c|}
\hline & $\beta$ & $t$ & $p$ \\
\hline \multicolumn{4}{|l|}{ DEPRESSION } \\
\hline \multicolumn{4}{|l|}{ DEMANDS } \\
\hline Fear of contamination & 0.014 & 0.336 & 0.737 \\
\hline Sleep-wake cycle problems & 0.619 & 12.139 & $<0.001$ \\
\hline Longing for touch & 0.135 & 3.038 & 0.003 \\
\hline Fear of the death of sign. others & 0.018 & 0.365 & 0.716 \\
\hline Domestic aggression & -0.024 & -0.532 & 0.595 \\
\hline Internet addiction & 0.076 & 1.645 & 0.102 \\
\hline Relationship with technology & 0.059 & 1.133 & 0.259 \\
\hline Work-life conflict & 0.042 & 0.682 & 0.496 \\
\hline Life-work conflict & 0.041 & 0.902 & 0.368 \\
\hline \multicolumn{4}{|l|}{ RESOURCES } \\
\hline Optimism & -0.061 & -1.352 & 0.178 \\
\hline Spirituality & -0.071 & -1.647 & 0.101 \\
\hline Social support & 0.033 & 0.698 & 0.486 \\
\hline \multicolumn{4}{|l|}{ Adjusted $R^{2}=0.66$} \\
\hline
\end{tabular}


Table 5. Sample split by the possibility of remote working correlations; YES $(\mathrm{N}=210)$ under the diagonal, $\mathrm{NO}(\mathrm{N}=89)$ above the diagonal.

\begin{tabular}{|c|c|c|c|c|c|c|c|c|c|c|c|c|c|c|c|c|c|c|}
\hline Measures & $\begin{array}{l}\text { YES } \\
\text { Mean } \\
\text { (SD) }\end{array}$ & $\begin{array}{l}\text { NO } \\
\text { Mean } \\
\text { (SD) }\end{array}$ & 1 & 2 & 3 & 4 & 5 & 6 & 7 & 8 & 9 & 10 & 11 & 12 & 13 & 14 & 15 & 16 \\
\hline 1.DEPRESSION & $\begin{array}{r}7.55 \\
(5.83)\end{array}$ & $\begin{array}{c}9.28 \\
(5.93)\end{array}$ & - & 0.214 & $0.222 *$ & $0.698^{* *}$ & 0.192 & 0.083 & $0.238^{*}$ & 0.199 & $0.327^{* *}$ & 0.136 & $0.282 *$ & $0.351 * *$ & -0.123 & -0.129 & -0.197 & 0.056 \\
\hline 2. E.E. & $\begin{array}{l}18.54 \\
(5.07)\end{array}$ & $\begin{array}{l}19.58 \\
(4.00)\end{array}$ & $0.604^{* *}$ & - & $0.339 * *$ & $0.267^{*}$ & 0.164 & 0.169 & 0.301 ** & $0.335^{* *}$ & $0.411^{* *}$ & $0.264^{*}$ & $0.580^{* *}$ & 0.015 & -0.155 & -0.118 & -0.111 & -0.128 \\
\hline $\begin{array}{l}\text { 3. FEAR } \\
\text { CONTAM. }\end{array}$ & $\begin{array}{l}18.43 \\
(8.23)\end{array}$ & $\begin{array}{l}21.26 \\
(8.34)\end{array}$ & $0.183^{* *}$ & 0.107 & - & $0.369^{* *}$ & 0.119 & 0.215 * & $0.264^{*}$ & 0.131 & 0.331 ** & 0.186 & 0.250 * & 0.051 & -0.179 & 0.042 & -0.189 & 0.056 \\
\hline $\begin{array}{c}4 . \\
\text { SLEEP-WAKE } \\
\text { PR. }\end{array}$ & $\begin{array}{l}29.54 \\
(12.54)\end{array}$ & $\begin{array}{c}33.99 \\
(13.22)\end{array}$ & $0.793 * *$ & $0.535^{* *}$ & $0.177^{*}$ & - & 0.175 & 0.188 & $0.274^{* *}$ & $0.271 *$ & $0.209 *$ & 0.074 & $0.274^{*}$ & 0.140 & -0.147 & -0.150 & $-0.216^{*}$ & 0.015 \\
\hline $\begin{array}{l}\text { 5. LONG. } \\
\text { TOUCH }\end{array}$ & $\begin{array}{c}9.13 \\
(4.89)\end{array}$ & $\begin{array}{l}10.03 \\
(5.03)\end{array}$ & $0.466^{* *}$ & $0.214^{* *}$ & 0.004 & 0.412 ** & - & 0.194 & $0.329 * *$ & $0.349^{* *}$ & -0.027 & 0.046 & $0.247^{*}$ & 0.026 & $-0.225^{*}$ & -0.081 & $-0.234^{*}$ & 0.082 \\
\hline 7. STIGMA & $\begin{array}{l}4.60 \\
(2.15)\end{array}$ & $\begin{array}{l}5.70 \\
(3.22)\end{array}$ & $0.213 * *$ & $0.243 * *$ & 0.113 & $0.237 * *$ & 0.139 * & 0.122 & - & 0.088 & 0.250 * & -0.041 & $0.328 * *$ & 0.154 & -0.046 & -0.068 & -0.033 & 0.121 \\
\hline $\begin{array}{l}\text { 8. DOM. } \\
\text { AGGR. }\end{array}$ & $\begin{array}{l}4.81 \\
(2.34)\end{array}$ & $\begin{array}{l}4.84 \\
(2.58)\end{array}$ & $0.201 *$ & $0.213^{* *}$ & -0.098 & $0.162 *$ & 0.155 * & 0.105 & 0.218 ** & - & $0.355^{* *}$ & $0.289 *$ & 0.338 ** & -0.022 & -0.127 & -0.202 & -0.156 & 0.139 \\
\hline $\begin{array}{l}\text { 9. INTERNET } \\
\text { ADD. }\end{array}$ & $\begin{array}{l}14.20 \\
(4.74)\end{array}$ & $\begin{array}{l}14.29 \\
(4.39)\end{array}$ & $0.196^{* *}$ & 0.135 & 0.139 * & 0.131 & $0.189^{* *}$ & 0.085 & $0.258 * *$ & 0.114 & - & $0.284^{* *}$ & 0.231 * & 0.027 & -0.132 & -0.086 & -0.069 & 0.021 \\
\hline $\begin{array}{l}\text { 10. RELAT. } \\
\text { TECH }\end{array}$ & $\begin{array}{l}10.74 \\
(4.53)\end{array}$ & $\begin{array}{c}9.83 \\
(4.29)\end{array}$ & $0.339^{* *}$ & 0.383 ** & 0.110 & $0.313^{* *}$ & 0.063 & -0.019 & 0.175 * & 0.069 & $0.305^{* *}$ & - & $0.475^{* *}$ & 0.030 & 0.071 & 0.097 & $-0.309 * *$ & -0.121 \\
\hline 11. W-LC & $\begin{array}{l}13.89 \\
(6.17)\end{array}$ & $\begin{array}{l}15.24 \\
(6.14)\end{array}$ & $0.436^{* *}$ & $0.583 * *$ & 0.125 & $0.395 * *$ & 0.072 & 0.052 & $0.215^{* *}$ & $0.283 * *$ & 0.190 ** & 0.582 ** & - & 0.208 & -0.159 & 0.092 & -0.195 & -0.115 \\
\hline 12. L-WC & $\begin{array}{l}9.16 \\
(4.20)\end{array}$ & $\begin{array}{l}9.21 \\
(4.33)\end{array}$ & $0.225 * *$ & $0.332 * *$ & 0.054 & 0.278 ** & -0.010 & -0.030 & 0.139 & 0.318 ** & 0.020 & $0.329 * *$ & 0.536 ** & - & -0.079 & 0.011 & -0.117 & -0.268 * \\
\hline $\begin{array}{c}13 . \\
\text { OPTIMISM }\end{array}$ & $\begin{array}{l}23.70 \\
(6.35)\end{array}$ & $\begin{array}{l}23.30 \\
(6.03)\end{array}$ & $-0.424 *$ & $-0.442 * *$ & $-0.166^{*}$ & $-0.362 * *$ & -0.180 ** & -0.060 & $-0.200 * *$ & $-0.203 * *$ & -0.067 & $-0.189 * *$ & $-0.409 * *$ & $-0.242 * *$ & - & $0.258^{*}$ & 0.198 & -0.025 \\
\hline $\begin{array}{l}\text { 15. SOC. } \\
\text { SUPPORT }\end{array}$ & $\begin{array}{l}24.82 \\
(5.33)\end{array}$ & $\begin{array}{l}24.80 \\
(5.15)\end{array}$ & $-0.234 * *$ & $-0.239 * *$ & 0.033 & $-0.233 * *$ & $-0.300^{* *}$ & $0.256^{* *}$ & 0.031 & -0.133 & -0.014 & $-0.249^{* *}$ & $-0.295^{* *}$ & $-0.257 * *$ & 0.290 ** & $0.157^{*}$ & - & 0.071 \\
\hline 16. AD. INFO & $\begin{array}{l}8.61 \\
(2.86)\end{array}$ & $\begin{array}{l}7.65 \\
(3.21)\end{array}$ & -0.198 ** & -0.077 & 0.048 & $-0.229 * *$ & -0.065 & -0.007 & -0.133 & $-0.184^{*}$ & 0.011 & $-0.198 * *$ & -0.130 & $-0.145^{*}$ & 0.123 & 0.051 & 0.108 & - \\
\hline
\end{tabular}

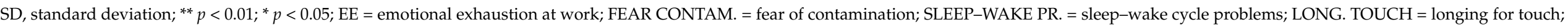

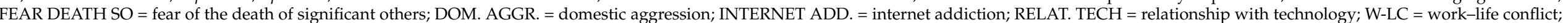

$\mathrm{L}-\mathrm{WC}=$ life-work conflict; SOC. SUPPORT = social support; AD. INFO = adequacy of information. 
Table 6. Regression model in the sample split by the possibility of remote working (depression = dependent variable).

\begin{tabular}{|c|c|c|c|c|c|c|}
\hline & & YES & & & NO & \\
\hline \multicolumn{7}{|l|}{ DEPRESSION } \\
\hline \multicolumn{6}{|l|}{ DEMANDS } & - \\
\hline Fear of contamination & 0.057 & 1.296 & 0.197 & -0.103 & -1.245 & 0.217 \\
\hline Sleep-wake cycle prob. & 0.588 & 10.452 & $<0.001$ & 0.652 & 8.012 & $<0.001$ \\
\hline Longing for touch & 0.145 & 3.028 & 0.003 & - & - & - \\
\hline Fear of the death of S.O. & 0.012 & 0.233 & 0.816 & - & - & - \\
\hline Stigma & -0.039 & -0.828 & 0.409 & -0.048 & -0.583 & 0.561 \\
\hline Domestic aggression & 0.032 & 0.676 & 0.500 & - & - & - \\
\hline Internet addiction & 0.011 & 0.218 & 0.828 & 0.215 & 2.645 & 0.010 \\
\hline Relationship with tech. & 0.117 & 2.091 & 0.038 & - & - & - \\
\hline Work-life conflict & 0.072 & 1.095 & 0.275 & 0.035 & 0.424 & 0.673 \\
\hline Life-work conflict & -0.076 & -1.475 & 0.143 & 0.258 & 3.360 & 0.001 \\
\hline \multicolumn{7}{|l|}{ RESOURCES } \\
\hline Optimism & -0.085 & -1.734 & 0.085 & - & - & - \\
\hline Spirituality & -0.114 & -2.588 & 0.011 & - & - & - \\
\hline Social support & 0.035 & 0.692 & 0.490 & - & - & - \\
\hline \multirow[t]{2}{*}{ Adequacy of information } & -0.046 & -1.053 & 0.294 & - & - & - \\
\hline & \multicolumn{3}{|c|}{ Adjusted $R^{2}=0.74$} & \multicolumn{3}{|c|}{ Adjusted $R^{2}=0.55$} \\
\hline
\end{tabular}

\section{Discussion}

The aim of this research was to understand the effects of the global COVID-19 pandemic on the psychological well-being of Italian workers, particularly those in northern Italy, the part of the nation first affected in a very serious way by the pandemic's impact. On the basis of a careful analysis of the present literature and the directly observable situation, specific demands and resources related both to the working context and to the social context created by the pandemic were identified. In order to obtain a more detailed view of the situation, the analyses were carried out with particular attention to the possibility of remote working.

From a more general point of view, although moderate levels of depression emerged, gender differences were found, with higher values in women. These results are in line with recent studies that have shown that women are a category that is at risk in pandemic situations, from the point of view of mental health, with particular reference to the risk of depression [48-50].

The analyses also showed that those who did not have the possibility of remote working experienced more depression than those who had this option. Given the particular context, it seems that those workers forced-by their own organization or by the intrinsic characteristics of their job-to go to work and meet other people during the lockdown had a negative experience due to their exposure to an increased risk of contagion. This outcome is confirmed, for example, by the results of studies on health personnel [51,52]—the most observed professional category with regard to the effects of COVID-19, but not only [53]. It is possible that being more at risk of having to go to work-rather than staying at home "safe"- has contributed significantly to the individual malaise of these workers.

The aim of this study was to verify five hypotheses.

The analyses partly confirmed the first hypothesis (H1), that specific demands related to the current pandemic context were positively linked to and predict depression. Among the demands considered-fear of contamination, sleep-wake cycle problems, longing for touch, fear of the death of significant others, stigma, domestic aggression, and internet addiction-sleep-wake cycle problems have proven to be a powerful predictor of depression both in the total sample and in the sample divided according to the possibility of remote working. This result confirms the conclusions of many longitudinal studies on 
the topic, in which people with sleep problems are more likely to develop depressive symptomatology [10-12]. Our findings are also consistent with evidence from international [54-57] and Italian [58-61] studies which observed a strong positive relationship between poor sleep quality and depression during the COVID-19 epidemic.

Longing for touch was also shown to predict depression in the total sample, which is in line with other recent studies that have shown that touch deprivation is linked to negative mental health outcomes [4,5]. Touch is, in fact, an important element for the well-being of the individual, as it decreases blood pressure and heartbeat and reduces cortisol levels in the blood, stimulating instead the production of oxytocin (for a review, see [62]). Further data on the role of touch deprivation as a predictor of depression in participants who had the option of working remotely were also revealed from this research. This result may indicate the lack of human contact experienced by those who were "isolated" at home, perhaps due to the lack of human relationships that they were previously used to experiencing in their work context, or due to the lack of human warmth in their private/domestic context, either because they were alone, perhaps, or because of a possible relational impoverishment reflecting the current deep social crisis.

As noted by previous studies, the pandemic situation has led to an increase in behavioral addictions, such as internet use, that are closely linked to mental health outcomes, including depression (for a review, see [9]). In this study, it emerged that internet addiction, in particular, had a positive relationship with depression in participants who did not have the possibility of remote working. Among the most recognized uses of the internet during the pandemic is not only leisure, but also the need to research and inquire [63]. This could indicate a greater need for those forced to go to work to seek information and news in order to find potential reassurance concerning the general risk situation to which they are most exposed.

Fear of being contaminated and stigma are factors that are ever-present in a pandemic context, especially for the most at-risk job categories. In the literature, a fear of contamination has been observed mainly in the general population [64] and in healthcare personnel [65-67], while stigma has been observed, for example, at the dispositional level of the general population toward health personnel [68]. There are currently no studies focused on non-healthcare sector work realities. In our study, although the analyses showed a strong and significant relationship of both fear of contamination and stigma with depression at the correlational level, no significant results emerged in the regression models.

A fear of contamination is also closely linked to death anxiety, especially fear of the death of loved ones. Several studies have shown that this type of fear is very strong during the COVID-19 pandemic $[69,70]$. In our case, a very significant relationship emerged at the correlational level, but not in the regression models.

This was also the case for domestic aggression, a risk factor to be taken into account in this particular context $[6,7]$. The analyses showed significant results only at a correlational level and not in the regression models.

As far as the second hypothesis (H2) is concerned, i.e., that specific demands related to the work context were positively linked to and predict depression, the analyses showed that two demands were predictors of depression. The first, life-work conflict, had a positive relationship with depression in participants who did not have the possibility of remote working. These results are in line with the literature, in which those who were working on-site, and therefore with a higher risk of exposure to COVID-19, showed higher levels of depression [53].

On the other hand, relationship with technology outside working hours was a predictor of depression in participants who had the possibility to carry out remote work. This result is particularly interesting, as there are few studies that have related technostress due to remote work-in particular, techno-invasion-to mental health outcomes [18] such as depression [71]. 
Emotional exhaustion at work was shown to be a predictor of depression (H3) in the total sample and in participants who had the option of remote working. This finding also reflects the evidence in the literature linking the experience of emotional exhaustion to an increased risk of the onset of depressive symptomatology [28,29]. The results also revealed an interesting fact regarding remote work: those who had this possibility seem to be more at risk of lower well-being, probably due to the continuous availability required (working longer than normal hours) and the difficulty of detaching from work, and due to a greater social isolation $[19,20]$.

The fourth hypothesis (H4), that specific personal resources-optimism and spirituality -were negatively linked to and predict depression, was only highlighted in part. In our study, optimism showed only significant correlations with depression in the total sample, a result obtained in other studies [72].

Spirituality, on the other hand, was a predictor of depression (in a negative way) only in participants with the option of remote working. This result is particularly interesting, because it sheds light on a topic that is still studied little in the field of mental health of those who work remotely: the protective role of spirituality in terms of the development of depressive symptomatology.

Recent evidence has shown that social support is an important resource that protects mental health in difficult times such as pandemics [73,74]. Nevertheless, in our sample, the last hypothesis (H5) was supported by correlations, but not by regression analyses.

Finally, although adequacy of information was considered an important resource to improve living in pandemic times [3], our study found significant results only at the level of correlations.

\section{Conclusions}

This research focused on the mental health of workers during the lockdown in northern Italy, the area of the country that was first and most-heavily affected by the COVID-19 pandemic. We identified some factors that may contribute to the onset of depression and others that may instead play a protective role in well-being. One of the main features of the study is that it focused on a heterogeneous sample of workers, unlike most studies on the subject, which have looked exclusively at health professionals. This allowed us to better observe the differences that may exist between remote workers and those who were forced to work on-site, for example, and to understand which factors have the potential to affect the quality of their working life. This research shows the importance of monitoring the health status of workers from other professional contexts that are currently less-studied than the healthcare sector, with particular interest in the opportunity, or lack thereof, to work remotely.

Despite the strength and potential contribution of this study to the investigation of workers' well-being in times of COVID-19, it is important to point out its limitations. First, this study has a cross-sectional design and a limited sample size. The non-probability sampling method, albeit useful when the population is very large and the aim of the study is exploratory and without the purpose of providing generalized results [75], also has limitations due to subjectivity in the selection of potential participants. Finally, it should be noted that in order to better understand a complex phenomenon such as the impact of a pandemic on mental health, it is useful to adopt an exploratory design in which more variables are considered. On the other hand, this approach may reduce the parsimony of the research model.

Author Contributions: Conceptualization, A.G., L.C., M.M. and L.S.; methodology, A.G., L.C. and M.M.; formal analysis, A.G. and L.C.; data curation, A.G. and L.C.; writing-original draft preparation, A.G.; writing-review and editing, A.G., L.C., M.M. and L.S.; visualization, A.G.; supervision, L.C. and M.M.; project administration, L.C. and M.M. All authors have read and agreed to the published version of the manuscript.

Funding: This research received no funding. 
Institutional Review Board Statement: The study was conducted according to the guidelines of the Declaration of Helsinki, and approved by the Bioethics Committee of the University of Turin (protocol code no. 181450).

Informed Consent Statement: Informed consent was obtained from all subjects involved in the study.

Data Availability Statement: The data from the study are available on request. The data are not publicly available due to the Italian legislation on privacy.

Conflicts of Interest: The authors declare no conflict of interest.

\section{References}

1. Fiorillo, A.; Gorwood, P. The consequences of the COVID-19 pandemic on mental health and implications for clinical practice. Eur. Psychiatry 2020, 63, 1-4. [CrossRef]

2. Rubin, G.J.; Wessely, S. The psychological effects of quarantining a city. BMJ 2020, 368, m313. [CrossRef] [PubMed]

3. Brooks, S.K.; Webster, R.; Smith, L.E.; Woodland, L.; Wessely, S.; Greenberg, N.; Rubin, G.J. The psychological impact of quarantine and how to reduce it: Rapid review of the evidence. Lancet 2020, 395, 912-920. [CrossRef]

4. Durkin, J.; Jackson, D.; Usher, K. Touch in times of COVID-19: Touch hunger hurts. J. Clin. Nurs. 2021, 30. [CrossRef] [PubMed]

5. Field, T.; Poling, S.; Mines, S.; Bendell, D.; Veazey, C. Touching and Touch Deprivation During a COVID-19 Lockdown. Int. J. Psychol. Res. Rev. 2020, 3, 42.

6. Campbell, A.M. An increasing risk of family violence during the COVID-19 pandemic: Strengthening community collaborations to save lives. Forensic Sci. Int. Rep. 2020, 2, 100089. [CrossRef]

7. Usher, K.; Bhullar, N.; Durkin, J.; Gyamfi, N.; Jackson, D. Family violence and COVID-19: Increased vulnerability and reduced options for support. Int. J. Ment. Health Nurs. 2020, 29, 549-552. [CrossRef]

8. Ramaci, T.; Pagliaro, S.; Teresi, M.; Barattucci, M. Job Demands and Negative Outcomes after the Lockdown: The Moderating Role of Stigma towards Italian Supermarket Workers. Sustainability 2021, 13, 7507. [CrossRef]

9. Masaeli, N.; Farhadi, H. Prevalence of Internet-based addictive behaviors during COVID-19 pandemic: A systematic review. J. Addict. Dis. 2021, 1-27. [CrossRef]

10. Baglioni, C.; Battagliese, G.; Feige, B.; Spiegelhalder, K.; Nissen, C.; Voderholzer, U.; Lombardo, C.; Riemann, D. Insomnia as a predictor of depression: A meta-analytic evaluation of longitudinal epidemiological studies. J. Affect. Disord. 2011, 135, 10-19. [CrossRef]

11. Hertenstein, E.; Feige, B.; Gmeiner, T.; Kienzler, C.; Spiegelhalder, K.; Johann, A.; Jansson-Fröjmark, M.; Palagini, L.; Rucker, G.; Riemann, D.; et al. Insomnia as a predictor of mental disorders: A systematic review and meta-analysis. Sleep Med. Rev. 2019, 43, 96-105. [CrossRef]

12. Li, L.; Wu, C.; Gan, Y.; Qu, X.; Lu, Z. Insomnia and the risk of depression: A meta-analysis of prospective cohort studies. BMC Psychiatry 2016, 16, 1-16. [CrossRef]

13. Carver, C.S.; Scheier, M.F.; Segerstrom, S.C. Optimism. Clin. Psychol. Rev. 2010, 30, 879-889. [CrossRef] [PubMed]

14. Gariépy, G.; Honkaniemi, H.; Quesnel-Vallée, A. Social support and protection from depression: Systematic review of current findings in Western countries. Br. J. Psychiatry 2016, 209, 284-293. [CrossRef]

15. Karakas, F. Spirituality and Performance in Organizations: A Literature Review. J. Bus. Ethics 2010, 94, 89-106. [CrossRef]

16. Barbuto, A.; Gilliland, A.; Peebles, R.; Rossi, N.; Shrout, T. Telecommuting: Smarter Workplaces Spring. 2020. Available online: https:/ / kb.osu.edu/bitstream/handle/1811/91648/AEDECON4567_Telecommuting_sp2020.pdf?sequence=1\&isAllowed=y (accessed on 21 April 2021).

17. La Torre, G.; Esposito, A.; Sciarra, I.; Chiappetta, M. Definition, symptoms and risk of techno-stress: A systematic review. Int. Arch. Occup. Environ. Health 2019, 92, 13-35. [CrossRef] [PubMed]

18. Dragano, N.; Lunau, T. Technostress at work and mental health: Concepts and research results. Curr. Opin. Psychiatry 2020, 33, 407-413. [CrossRef] [PubMed]

19. Barone Gibbs, B.; Kline, C.E.; Huber, K.A.; Paley, J.L.; Perera, S. COVID-19 shelter-at-home and work, lifestyle and well-being in desk workers. Occup. Med. (Chic. Ill). 2021, 71, 86-94. [CrossRef]

20. Charalampous, M.; Grant, C.A.; Tramontano, C.; Michailidis, E. Systematically reviewing remote e-workers' well-being at work: A multidimensional approach. Eur. J. Work. Organ. Psychol. 2019, 28, 51-73. [CrossRef]

21. Seidler, A.; Thinschmidt, M.; Deckert, S.; Then, F.; Hegewald, J.; Nieuwenhuijsen, K.; Riedel-Heller, S.G. The role of psychosocial working conditions on burnout and its core component emotional exhaustion-A systematic review. J. Occup. Med. Toxicol. 2014, 9, 10. [CrossRef] [PubMed]

22. Castelli, L.; Di Tella, M.; Benfante, A.; Romeo, A. The Spread of COVID-19 in the Italian Population: Anxiety, Depression, and Post-traumatic Stress Symptoms. Can. J. Psychiatry 2020, 65, 731-732. [CrossRef]

23. Fiorillo, A.; Sampogna, G.; Giallonardo, V.; Del Vecchio, V.; Luciano, M.; Albert, U.; Carmassi, C.; Carrà, G.; Cirulli, F.; Dell'Osso, B.; et al. Effects of the lockdown on the mental health of the general population during the COVID-19 pandemic in Italy: Results from the COMET collaborative network. Eur. Psychiatry 2020, 63, 1-28. [CrossRef] [PubMed] 
24. Ganson, K.T.; Tsai, A.C.; Weiser, S.D.; Benabou, S.E.; Nagata, J.M. Job Insecurity and Symptoms of Anxiety and Depression among U.S. Young Adults During COVID-19. J. Adolesc. Health 2020, 68, 53-56. [CrossRef] [PubMed]

25. Giorgi, G.; Lecca, L.I.; Alessio, F.; Finstad, G.L.; Bondanini, G.; Lulli, L.G.; Arcangeli, G.; Mucci, N. COVID-19-related mental health effects in the workplace: A narrative review. Int. J. Environ. Res. Public Health 2020, 17, 7857. [CrossRef] [PubMed]

26. Huang, Y.; Zhao, N. Generalized anxiety disorder, depressive symptoms and sleep quality during COVID-19 outbreak in China: A web-based cross-sectional survey. Psychiatry Res. 2020, 288, 112954. [CrossRef] [PubMed]

27. Pereira, H.; Feher, G.; Tibold, A.; Costa, V.; Monteiro, S.; Esgalhado, G. Mediating Effect of Burnout on the Association between Work-Related Quality of Life and Mental Health Symptoms. Brain Sci. 2021, 11, 813. [CrossRef]

28. Brenninkmeyer, V.; Van Yperen, N.W.; Buunk, B.P. Burnout and depression are not identical twins: Is decline of superiority a distinguishing feature? Pers. Individ. Dif. 2001, 30, 873-880. [CrossRef]

29. Iacovides, A.; Fountoulakis, K.N.; Kaprinis, S.; Kaprinis, G. The relationship between job stress, burnout and clinical depression. J. Affect Disord. 2003, 75, 209-221. [CrossRef]

30. Bakker, A.B.; Demerouti, E. Job Demands-Resources Theory. In Wellbeing: A Complete Reference Guide Volume 3 Work and Wellbeing; Chen, P.Y., Cooper, C.L., Eds.; John Wiley \& Sons, Ltd.: Hoboken, NJ, USA, 2014; pp. 37-64.

31. Kroenke, K.; Strine, T.W.; Spitzer, R.L.; Williams, J.B.; Berry, J.T.; Mokdad, A.H. The PHQ-8 as a measure of current depression in the general population. J. Affect. Disord. 2009, 114, 163-173. [CrossRef]

32. Demerouti, E.; Mostert, K.; Bakker, A.B. Burnout and work engagement: A thorough investigation of the independency of both constructs. J. Occup. Health Psychol. 2010, 15, 209-222. [CrossRef]

33. Sanavio, E. Obsessions and compulsions: The Padua inventory. Behav. Res. Ther. 1988, 26, 169-177. [CrossRef]

34. Natale, V.; Fabbri, M.; Tonetti, L.; Martoni, M. Psychometric goodness of the Mini Sleep Questionnaire. Psychiatry Clin. Neurosci. 2014, 68, 568-573. [CrossRef] [PubMed]

35. Punyanunt-Carter, N.M.; Wrench, J.S. Development and Validity Testing of a Measure of Touch Deprivation. Hum. Commun. 2009, 12, 67-76.

36. Neimeyer, R.A.; Moore, M.K. Validity and reliability of the Multidimensional Fear of Death Scale. In Death Anxiety Handbook: Research, Instrumentation, and Application; Neimeyer, R.A., Ed.; Taylor \& Francis: Boca Raton, FL, USA, $1994 ;$ pp. $103-119$.

37. Wahl, O.F. Mental Health Consumers' Experience of Stigma. Schizophr. Bull. 1999, 25, 467-478. [CrossRef]

38. Signorelli, M.S.; Arcidiacono, E.; Musumeci, G.; DI Nuovo, S.; Aguglia, E. Detecting Domestic Violence: Italian Validation of Revised Conflict Tactics Scale (CTS-2). J. Fam. Violence 2014, 29, 361-369. [CrossRef]

39. Straus, M.A.; Hamby, S.L.; Boney-McCoy, S.; Sugarman, D.B. The revised conflict tactics scales (CTS2) development and preliminary psychometric data. J. Fam. Issues. 1996, 17, 283-316. [CrossRef]

40. Karadă̆, E.; Tosuntaş, Ş.B.; Erzen, E.; Duru, P.; Bostan, N.; Şahin, B.M.; Çulha, İ.; Babadă̆, B. Determinants of phubbing, which is the sum of many virtual addictions: A structural equation model. J. Behav. Addict. 2015, 4, 60-74. [CrossRef]

41. Netemeyer, R.G.; Boles, J.S.; McMurrian, R. Development and validation of work-family conflict and family-work conflict scales. J. Appl. Psychol. 1996, 81, 400-410. [CrossRef]

42. Colombo, L.; Ghislieri, C. The work-to-family conflict: Theories and measures. TPM-Testing. Psychom. Methodol. Appl. Psychol. 2008, 15, 35-55.

43. Giannini, M.; Schuldberg, D.; Di Fabio, A.; Gargaro, D. Misurare l'ottimismo: Proprietà psicometriche della versione Italiana del Life Orientation Test-Revised (LOT-R). Couns. G. Ital. Ric. Appl. 2008, 1, 73-83.

44. Scheier, M.F.; Carver, C.S.; Bridges, M.W. Distinguishing Optimism from Neuroticism (and Trait Anxiety, Self-Mastery, and Self-Esteem): A Reevaluation of the Life Orientation Test. J. Pers. Soc. Psychol. 1994, 67, 1063-1078. [CrossRef]

45. Underwood, L.G.; Teresi, J.A. The daily spiritual experience scale: Development, theoretical description, reliability, exploratory factor analysis, and preliminary construct validity using health-related data. Ann. Behav. Med. 2002, 24, 22-33. [CrossRef]

46. Mitchell, P.H.; Powell, L.; Blumenthal, J.; Norten, J.; Ironson, G.; Pitula, C.R.; Froelicher, E.S.; Czajkowski, S.; Youngblood, M.; Huber, M.; et al. A short social support measure for patients recovering from myocardial infarction: The ENRICHD Social Support Inventory. J. Cardiopulm. Rehabil. 2003, 23, 398-403. [CrossRef]

47. Hayes, A.F.; Coutts, J.J. Use Omega Rather than Cronbach's Alpha for Estimating Reliability. But ... . Commun. Methods Meas. 2020, 14, 1-24. [CrossRef]

48. Connor, J.; Madhavan, S.; Mokashi, M.; Amanuel, H.; Johnson, N.R.; Pace, L.E.; Bartz, D. Health risks and outcomes that disproportionately affect women during the COVID-19 pandemic: A review. Soc. Sci. Med. 2020, 266, 113364. [CrossRef]

49. González-Sanguino, C.; Ausín, B.; Castellanos, M.; Saiz, J.; López-Gómez, A.; Ugidos, C.; Muñoz, M. Mental health consequences during the initial stage of the 2020 Coronavirus pandemic (COVID-19) in Spain. Brain Behav. Immun. 2020, 87, 172-176. [CrossRef] [PubMed]

50. Mazza, C.; Ricci, E.; Biondi, S.; Colasanti, M.; Ferracuti, S.; Napoli, C.; Roma, P. A Nationwide Survey of Psychological Distress among Italian People during the COVID-19 Pandemic: Immediate Psychological Responses and Associated Factors. Int. J. Environ. Res. Public Health 2020, 17, 3165. [CrossRef]

51. Lenzo, V.; Quattropani, M.C.; Sardella, A.; Martino, G.; Bonanno, G.A. Depression, Anxiety, and Stress Among Healthcare Workers During the COVID-19 Outbreak and Relationships with Expressive Flexibility and Context Sensitivity. Front. Psychol. 2021, 12, 623033. [CrossRef] [PubMed] 
52. Pappa, S.; Ntella, V.; Giannakas, T.; Giannakoulis, V.; Papoutsi, E.; Katsaounou, P. Prevalence of depression, anxiety, and insomnia among healthcare workers during the COVID-19 pandemic: A systematic review and meta-analysis. Brain Behav. Immun. 2020, 88, 901-907. [CrossRef] [PubMed]

53. Wickens, C.M.; Hamilton, H.A.; Elton-Marshall, T.; Nigatu, Y.T.; Jankowicz, D.; Wells, S. Household- and employment-related risk factors for depressive symptoms during the COVID-19 pandemic. Can. J. Public Health 2021, 112, 391-399. [CrossRef] [PubMed]

54. Zhang, Y.; Wang, S.; Ding, W.; Meng, Y.; Hu, H.; Liu, Z.; Zeng, X.; Guan, Y.; Wang, M. Status and influential factors of anxiety depression and insomnia symptoms in the work resumption period of COVID-19 epidemic: A multicenter cross-sectional study. J. Psychosom. Res. 2020, 138, 110253. [CrossRef] [PubMed]

55. Al-Ajlouni, Y.A.; Park, S.H.; Alawa, J.; Shamaileh, G.; Bawab, A.; El-Sadr, W.M.; Duncan, D.T. Anxiety and depressive symptoms are associated with poor sleep health during a period of COVID-19-induced nationwide lockdown: A cross-sectional analysis of adults in Jordan. BMJ Open 2020, 10, e041995. [CrossRef]

56. Majumdar, P.; Biswas, A.; Sahu, S. COVID-19 pandemic and lockdown: Cause of sleep disruption, depression, somatic pain, and increased screen exposure of office workers and students of India. Chrono- Int. 2020, 37, 1191-1200. [CrossRef] [PubMed]

57. Barros, M.B.; Lima, M.G.; Malta, D.C.; Szwarcwald, C.L.; Azevedo, R.C.; Romero, D.; Souza Júnior, P.R.; Azevedo, L.O.; Machado, Í.E.; Damacena, G.N.; et al. Report on sadness/depression, nervousness/anxiety and sleep problems in the Brazilian adult population during the COVID-19 pandemic. Epidemiol. Serviços Saúde 2020, 29, e2020427. [CrossRef]

58. Bacaro, V.; Chiabudini, M.; Buonanno, C.; De Bartolo, P.; Riemann, D.; Mancini, F.; Baglioni, C. Insomnia in the Italian Population During COVID-19 Outbreak: A Snapshot on One Major Risk Factor for Depression and Anxiety. Front. Psychiatry 2020, $11,579107$. [CrossRef] [PubMed]

59. Franceschini, C.; Musetti, A.; Zenesini, C.; Palagini, L.; Scarpelli, S.; Quattropani, M.C.; Lenzo, V.; Freda, M.F.; Lemmo, D.; Vegni, E.; et al. Poor Sleep Quality and Its Consequences on Mental Health During the COVID-19 Lockdown in Italy. Front. Psychol. 2020, 11, 574475. [CrossRef]

60. Gualano, M.R.; Moro, G.L.; Voglino, G.; Bert, F.; Siliquini, R. Effects of COVID-19 Lockdown on Mental Health and Sleep Disturbances in Italy. Int. J. Environ. Res. Public Health 2020, 17, 4779. [CrossRef]

61. Rossi, R.; Socci, V.; Talevi, D.; Mensi, S.; Niolu, C.; Pacitti, F.; Di Marco, A.; Rossi, A.; Siracusano, A.; Di Lorenzo, G. COVID-19 Pandemic and Lockdown Measures Impact on Mental Health Among the General Population in Italy. Front. Psychiatry 2020, 11, 790. [CrossRef]

62. Field, T. Touch for socioemotional and physical well-being: A review. Dev. Rev. 2010, 30, 367-383. [CrossRef]

63. Mehta, S.K.; Murkey, B. Effect of COVID-19 pandemic imposed lockdown on internet addiction. IAHRW Int. J. Soc. Sci. Rev. 2020, 8, 285-290.

64. Knowles, K.A.; Olatunji, B.O. Anxiety and safety behavior usage during the COVID-19 pandemic: The prospective role of contamination fear. J. Anxiety Disord. 2021, 77, 102323. [CrossRef] [PubMed]

65. Gorini, A.; Fiabane, E.; Sommaruga, M.; Barbieri, S.; Sottotetti, F.; La Rovere, M.T.; Tremoli, E.; Gabanelli, P. Mental health and risk perception among Italian healthcare workers during the second month of the COVID-19 pandemic. Arch. Psychiatr. Nurs. 2020, 34, 537-544. [CrossRef] [PubMed]

66. Hu, D.; Kong, Y.; Li, W.; Han, Q.; Zhang, X.; Zhu, L.X.; Wan, S.W.; Liu, Z.; Shen, Q.; Yang, J.; et al. Frontline nurses' burnout, anxiety, depression, and fear statuses and their associated factors during the COVID-19 outbreak in Wuhan, China: A large-scale cross-sectional study. EClinicalMedicine 2020, 24, 100424. [CrossRef]

67. Kumar, J.; Katto, M.S.; Siddiqui, A.A.; Sahito, B.; Ahmed, B.; Jamil, M.; Ali, M. Predictive Factors Associated with Fear Faced by Healthcare Workers During COVID-19 Pandemic: A Questionnaire-Based Study. Cureus 2020, 12, e9741. [CrossRef]

68. Taylor, S.; Landry, C.A.; Rachor, G.S.; Paluszek, M.M.; Asmundson, G.J. Fear and avoidance of healthcare workers: An important, under-recognized form of stigmatization during the COVID-19 pandemic. J. Anxiety Disord. 2020, 75, 102289. [CrossRef]

69. Lázaro-Pérez, C.; Martínez-López, J.; Gómez-Galán, J.; Fernández-Martínez, A.M.D.M. COVID-19 Pandemic and Death Anxiety in Security Forces in Spain. Int. J. Environ. Res. Public Health 2020, 17, 7760. [CrossRef]

70. Martínez-López, J.; Lázaro-Pérez, C.; Gómez-Galán, J. Death Anxiety in Social Workers as a Consequence of the COVID-19 Pandemic. Behav. Sci. 2021, 11, 61. [CrossRef] [PubMed]

71. Reinecke, L.; Aufenanger, S.; Beutel, M.E.; Dreier, M.; Quiring, O.; Stark, B.; Wölfling, K.; Müller, K.W. Digital Stress over the Life Span: The Effects of Communication Load and Internet Multitasking on Perceived Stress and Psychological Health Impairments in a German Probability Sample. Media Psychol. 2017, 20, 90-115. [CrossRef]

72. Arslan, G.; Yıldırım, M. Coronavirus stress, meaningful living, optimism, and depressive symptoms: A study of moderated mediation model. Aust. J. Psychol. 2021, 73, 113-124. [CrossRef]

73. Grey, I.; Arora, T.; Thomas, J.; Saneh, A.; Tohme, P.; Abi-Habib, R. The role of perceived social support on depression and sleep during the COVID-19 pandemic. Psychiatry Res. 2020, 293, 113452. [CrossRef]

74. Hou, T.; Zhang, T.; Cai, W.; Song, X.; Chen, A.; Deng, G.; Ni, C. Social support and mental health among health care workers during Coronavirus Disease 2019 outbreak: A moderated mediation model. PLoS ONE 2020, 15, e0233831. [CrossRef] [PubMed]

75. Etikan, I.; Musa, S.A.; Alkassim, R.S. Comparison of Convenience Sampling and Purposive Sampling. Am. J. Theor. Appl. Stat. 2016, 5, 1. [CrossRef] 